\title{
SELECTED ASPECTS OF MANUFACTURING STRUCTURAL ELEMENTS FROM TITANIUM ALLOYS COMBINING COST- EFFECTIVE POWDER METALLURGY TECHNOLOGY AND METAL FORMING PROCESSES
}

\author{
KRYSTIAN ZYGULA*, MAREK WOJTASZEK, TOMASZ ŚLEbODA, OLEKSANDR LYPCHANSKYI \\ AGH University of Science and Technology, al. Mickiewicza 30, 30-059 Krakow, Poland \\ *Corresponding author: kzygula@agh.edu.pl
}

\begin{abstract}
Titanium alloys are mainly used in the automotive, aviation, shipbuilding and military industries. Their main advantages are low specific gravity, resistance to cracking and corrosion, high strength as well as fatigue strength. The most important disadvantages of titanium alloys include low thermal conductivity, difficulties in their machining and high cost of manufacturing. For the latter reason, titanium alloys are primarily used for the manufacturing of highly responsible components, such as implants and aviation structures, while the remaining products are produced in limited series. In the appropriate conditions, many titanium alloys can be formed in hot working processes. At present, in the processes of manufacturing structural elements of titanium alloys, semi-finished products obtained by the casting method are commonly used. However, more and more research is being carried out on the use of powder metallurgy based material in this field. This approach opens up the possibility of decreasing production costs. As initial material, the alloy powders or mixtures of elemental powders can be used. The properties of alloy powder products are usually high and stable, however, the cost of powder production is high. Obtaining a product from titanium alloys based on a powders mixture is relatively simple and significantly cheaper. The disproportion of prices causes, that a great number of research projects realized in recent years in the field of implementation of powder metallurgy for manufacturing titanium-based products is directed towards the use of powder mixtures since this approach gives real chances for the successful implementation of costeffective titanium alloys processing technology.
\end{abstract}

Key words: Titanium alloys, Powder metallurgy, Elemental powders, Metal forming

\section{INTRODUCTION}

Titanium alloys are mainly used as highperformance components and mostly applied in the aviation industry due to low density, high mechanical properties and good corrosion resistance (Singh et al., 2017). Moreover, the biocompatibility of some of the titanium alloys allows using them in medicine as a bone replacement (Chouirfa et al., 2019; Eisenbarth et al., 2004). High affinity to oxygen and nitrogen and low thermal conductivity, which makes titanium alloys difficult to machine, have caused the costs of the production by conventional methods relatively high (Singh et al., 2017). The powder met- allurgy (PM) method seems to be a cost-effective alternative as a production method, which allows manufacturing net-shape or near-net-shape elements. Recent studies have shown, that application of powder metallurgy techniques can result in decreasing the manufacturing costs as well as in obtaining products having as good mechanical properties as titanium alloys made by ingot metallurgy (Kim et al., 2014; Zyguła et al., 2017; Dunstan et al., 2019). Different procedures were applied to manufacturing semi-products from titanium powders. A method providing the best microstructural homogeneity and mechanical properties is hot isostatic pressing (HIP) 
of pre-alloyed titanium powders. However, this method is much more expensive in comparison to, for example, cold pressing and sintering of elemental powders mixtures (Yang et al., 2018b).

An important factor having an influence on further mechanical properties of the material is its microstructure. In the case of titanium alloys, shape, morphology and location of $\alpha$ grains play a significant role in designing their properties. The control of the microstructure of titanium alloy made by the powder metallurgy technique can be performed in various ways. First of all, the appropriate schedule of sintering process, which can be combined or followed by heat treatment, results in the formation of microstructure containing the combination of $\alpha$ and $\beta$ phases or single-phase $\beta$ structure (Ma et al., 2018). The hot deformation processes applied to the titanium powder compact can result in homogenous and fine microstructure throughout dynamic recrystallization (DRX). Additionally, fragmentation of $\alpha$ grain boundaries, due to thermo-mechanical processes (TMP), results in increase in ductility of titanium alloy (Ahmed et al., 2017). All mentioned effects, combined with decreasing the porosity of PM material, plays significant role in increasing mechanical properties of structural element obtained from powder metallurgy titanium alloy.

The research work contains chosen aspects of manufacturing structural elements from Ti alloys with an application of the cost-effective approach, involving plastic forming of semi-products obtained by the application of powder metallurgy technology. The results obtained for several selected titanium alloys are presented, however in each case mixtures of elemental powders were used as the initial material. Chosen investigations of the properties of semifinished products obtained from powders are presented. Then, selected results of the research on the influence of thermal and mechanical parameters of hot processing on the microstructure and selected properties of titanium alloy products have been compiled. These results were obtained on the basis of plastometric tests, and as the result of the application of analytical methods as well as on the basis of tests carried out under industrial conditions.

\section{EXPERIMENTAL PROCEDURE}

The initial materials used for experimental research were three different titanium alloys (Ti-6Al$4 \mathrm{~V}$, Ti-10V-2Fe-3Al, Ti-5Al-5Mo-5V-3Cr) made by techniques based on powder metallurgy methods. Nominal chemical compositions of the alloys are given in table 1. Raw materials used for making powders mixtures were elemental powders of titanium (hydrogenation-dehydrogenation - HDH, 100 mesh), aluminum (atomized, up to $35 \mu \mathrm{m}$ ), vanadium (HDH, 100 mesh), iron (atomized, 100 mesh) and chromium (milled, $>63 \mu \mathrm{m}$ ). The powders were weighed in the proportions required for achieving a nominal composition of a specific titanium alloy and then mixed for 90 minutes in a conical mixer with a rotational speed of $55 \mathrm{rpm}$. For improving the efficiency of the blending process, tungsten carbide (WC) balls were added to the container with powders. Then, powders mixtures were hot-pressed (HP) at $1200{ }^{\circ} \mathrm{C}$ under pressure of $25 \mathrm{MPa}$ for $3 \mathrm{~h}$ in the case of Ti-6Al-4V and Ti-10V-2Fe-3Al alloys, and for $45 \mathrm{~min}$ in the case of Ti-5 Al-5Mo-5V-3Cr alloy. The process was carried out under an argon protective atmosphere. In the result of the HP process, cylindrical compacts of $77.5 \mathrm{~mm}$ in diameter and about $40 \mathrm{~mm}$ high were obtained. Additionally, the Ti-5Al-5Mo-5V-3Cr alloy powder mixture was compacted at room temperature and then sintered (CPS - cold pressing and sintering) at the temperature of $1250{ }^{\circ} \mathrm{C}$ for $4 \mathrm{~h}$ under protective atmosphere (argon). After compaction relative density of the obtained compacts was measured using the Archimedes method.

In order to analyze the chemical composition of powders mixtures as well as that of the obtained compacts, Energy-dispersive X-ray spectroscopy (EDS) analysis (Hitachi HM-3000 scanning microscope) was performed. The hot compression tests were carried out to determine the flow behavior of the investigated materials (Gleeble 3800 Thermal Physical Simulator; Servo-Hydraulic Hot Deformation Simulator WUMSI; Bähr MDS 830 Thermomechanical Simulator). The tests were performed at a wide range of temperatures $\left(800-1100^{\circ} \mathrm{C}\right)$ and strain rates $\left(0.01-100 \mathrm{~s}^{-1}\right)$.

Table 1. Nominal chemical composition of the investigated alloys (in \% by weight).

\begin{tabular}{|c|c|c|c|c|c|c|}
\hline Alloy / Element & $\mathrm{Al}$ & $\mathrm{V}$ & $\mathrm{Fe}$ & $\mathrm{Mo}$ & $\mathrm{Cr}$ & $\mathrm{Ti}$ \\
\hline $\mathrm{Ti}-6 \mathrm{Al}-4 \mathrm{~V}$ & $5.5-6.75$ & $3.5-4.5$ & $>0.3$ & - & - & \multirow{2}{*}{ balance } \\
\cline { 1 - 6 } $\mathrm{Ti}-10 \mathrm{~V}-2 \mathrm{Fe}-3 \mathrm{Al}$ & $2.6-3.4$ & $9-11$ & $1.6-2.2$ & - & - & \\
\hline Ti-5Al-5Mo-5V-3Cr & $4.4-5.7$ & $4.0-5.5$ & - & $4.0-5.5$ & $2.5-3.5$ & \\
\hline
\end{tabular}


Based on the Dynamic Material Model (DMM) theory, as well as on data from hot compression tests, processing maps for the investigated alloys were elaborated. For the calculations, a method based on the equations previously reported by Prasad et al. (1984) was used. Numerical simulations of chosen forging processes were realized with the application of the Finite Element Method (FEM), using QForm 2D/3D commercial software. Forging tests in industrial conditions were performed at GK Forge Grelowski forging company in Poland and at ATI forging company, Poland.

Mechanical properties of all materials, including the uniaxial compression tests, tensile tests (ZwickRoell Z250 testing machine) and hardness measurements (Zwick-Nolan), were carried out for the investigated materials before and after deformation processes. Optical microscopy (Leica DM4000M) was used to analyse the microstructure after the manufacturing process, as well as after forging processes. Ground and polish cross-sections of each investigated sample were etched with Kroll's reagent ( 2 vol. $\% \mathrm{HF}+2$ vol. \% $\mathrm{HNO} 3+94$ vol. \% H2O).

\section{RESULTS AND DISCUSSION}

\subsection{Initial materials and compacts characteri- zation}

The results of EDS analysis for the chosen powder mixture were shown in figure 1. Regardless of the chemical composition, it has been observed, that due to the intensive blending process with the application of WC balls softer particles (e.g. aluminum) were inserted on the surfaces of harder particles and also some of the ingredients were crushed and fragmented. Such effect is beneficial for further homogenization of the chemical composition and microstructure.

Due to the hot compaction process of the Ti$6 \mathrm{Al}-4 \mathrm{~V}$ alloy powder mixture and of Ti-10V-2Fe$3 \mathrm{Al}$ alloy powder mixture in extended time, the obtained materials were characterized by high density and uniform microstructure. In the case of Ti-5Al$5 \mathrm{Mo}-5 \mathrm{~V}-3 \mathrm{Cr}$ alloy, a shorter time of compacting resulted in formation of areas with high concentration of $\beta$ - stabilizing elements, but this had no impact on relative density, which was comparable with the density of other investigated materials. Microstructure observations revealed, that HP materials did not have significant porosity. Ti-5Al-5Mo-5V-
3Cr powders mixture subjected to the CPS process was characterized by significantly lower relative density and evident porosity. Nevertheless, due to carefully selected time of sintering, homogenous and uniform microstructure was obtained. A comparison of relative density with respect to the chemical composition and method of manufacturing was shown in figure 2 .
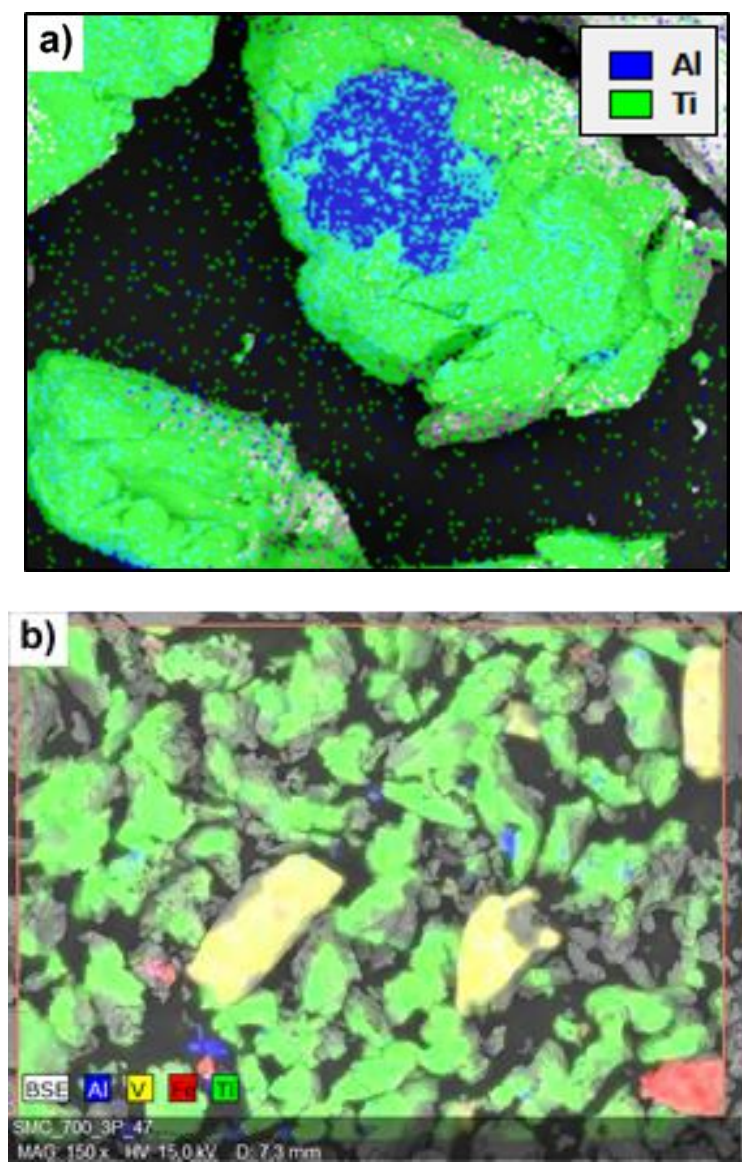

Fig. 1. EDS analysis results: a) Al particles inserted on $T i$ particle in Ti-6Al-4V alloy powder mixture, $b$ ) identification of the chemical composition of the powder particles in Ti-10V$2 \mathrm{Fe}-3 \mathrm{Al}$ alloy powder mixture.

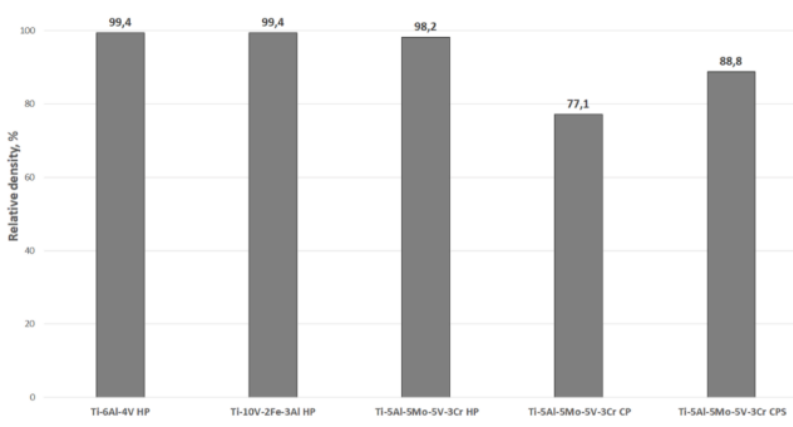

Fig. 2. Comparison of the relative density of the investigated materials manufactured by the powder metallurgy method. 
Conducted studies revealed, that the most important role in proper homogenization of the microstructure plays the time and temperature of sintering. Basing of the previous research performed by Ivasishin and Savvakin (2010) and Yang et al. (2018a) for titanium alloys manufactured by BEPM technique, it may be stated, that sintering process should be conducted at the temperature between $1200^{\circ} \mathrm{C}-1350^{\circ} \mathrm{C}$ and in time no shorter than 2 hours. Such processing parameters ensure complete alloying of powder particles by dissolving into the titanium matrix and also are sufficient for self-diffusion of titanium. The microstructures of as-manufactured materials were shown in figure 3. Materials compacted in the HP process and slowly cooled in die (figure $3 \mathrm{a}-\mathrm{c}$ ), regardless of the chemical composition, were characterized by the microstructure composed of thick lamellar $\alpha$ grains located on primary $\beta$ grains boundaries and within them. In the case of $\beta$ titanium alloys, $\beta$ phase fraction was greater (figure $3 b-c$ ). Such microstructure was previously observed by Carman et al. (2011) as a result of slow furnace cooling after heat treatment of $\mathrm{PM} \mathrm{Ti}-5 \mathrm{Al}-5 \mathrm{~V}-5 \mathrm{Mo}-2 \mathrm{Cr}-1 \mathrm{Fe}$ alloy. The microstructure of cold compacted and sintered material (figure 3d) was mainly composed of thin $\alpha$ plates located on primary $\beta$ grain boundaries and small $\alpha$ acicular precipitations located perpendicular to each other and spread inside primary $\beta$ grain on $\beta$ phase matrix.

Regardless of the chemical composition, all investigated alloys exhibit high tensile strength, but low elongation in comparison to the material of corresponding chemical composition, manufactured by conventional casting route. Selected mechanical properties of the investigated materials in the asmanufactured state were shown in table 2 .

Table 2. Data used for material description in numerical modeling, $Y_{S}$ -Yield strength, UTS - ultimate tensile strength, A - elongation, $Y_{S C}$ yield strength in compression, $\mathrm{HV}_{2}$ - hardness.

\begin{tabular}{|c|c|c|c|c|c|}
\hline & $\begin{array}{c}Y_{s} \\
\text { MPa }\end{array}$ & $\begin{array}{c}\text { UTS } \\
\text { MPa }\end{array}$ & $\begin{array}{c}A \\
\%\end{array}$ & $\begin{array}{c}Y_{S C} \\
\text { MPa }\end{array}$ & $H V_{2}$ \\
\hline Ti-6Al-4V & 950 & 1022 & 5.9 & - & 338 \\
\hline Ti-10V-2Fe-3Al & - & 982 & 9.0 & 2173 & 330 \\
\hline $\begin{array}{c}\text { Ti-5Al-5V-5Mo-3Cr } \\
\text { (HP) }\end{array}$ & - & - & - & 1894 & 401 \\
\hline $\begin{array}{c}\text { Ti-5Al-5V-5Mo-3Cr } \\
\text { (CPS) }\end{array}$ & - & - & - & 1537 & 220 \\
\hline
\end{tabular}
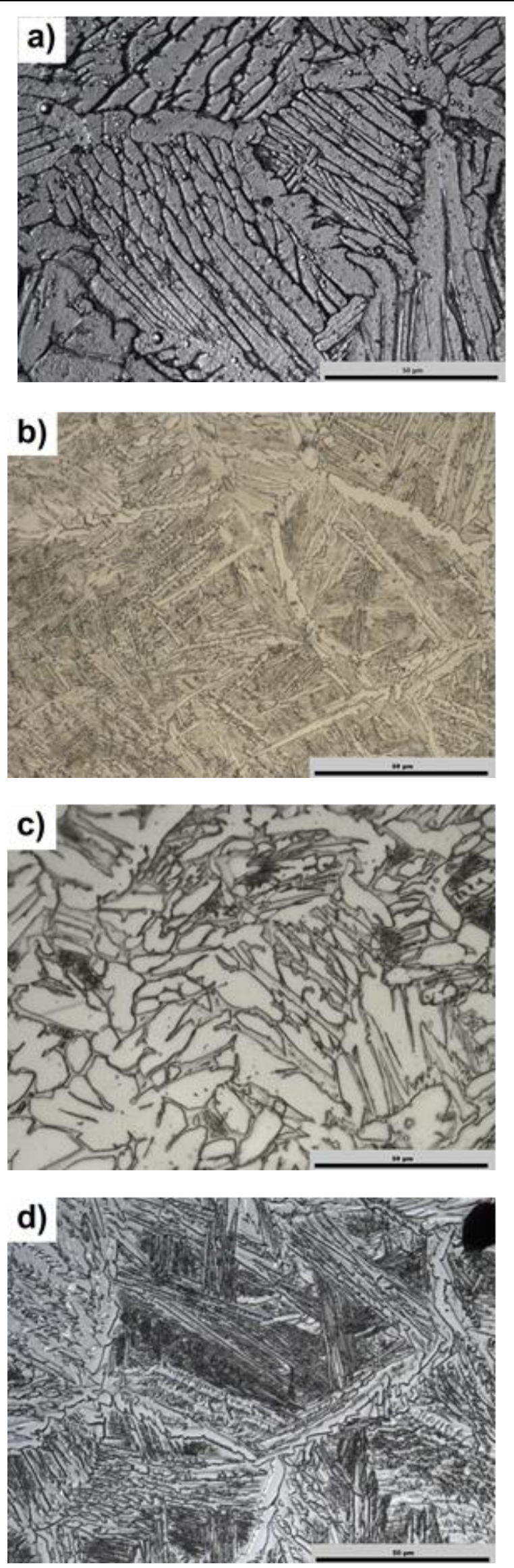

Fig. 3. Microstructures of as-manufactured: a) Ti-6Al-4V alloy, b) Ti-10V-2Fe-3Al alloy, c) Ti-5Al-5V-5Mo-3Cr alloy $(\mathrm{HP}), d$ ) Ti-5Al-5V-5Mo-3Cralloy (CPS). 


\subsection{Flow behavior}

The investigated materials were tested in a wide range of temperatures and strain rates. The hot compression process was scheduled according to the scheme presented in figure $4 \mathrm{a}$. The results of the discussed flow behavior of the examined alloys were previously reported by Wojtaszek and Śleboda (2013, 2014), Wojtaszek et al. (2014, 2016), and Zyguła et al. (2017, 2019). Tests were performed using different types of thermo-mechanical simulators, which were able to simulate various ranges of processing conditions. It was indicated, that titanium alloys made by powder metallurgy technique are very sensitive to variable parameters of processing, such as temperature and strain rate. Flow curves received at low temperature or high strain rate are characterized by stress peak followed by flow softening and steady-state behavior. Increasing the temperature of deformation and decreasing strain rate resulted in reduction of flow stress phenomenon.

Chosen flow curves for $\alpha+\beta$ titanium alloy and $\beta$ titanium alloy were presented in figure $4 \mathrm{~b}$. Irrespectively on chemical composition, at high strain rates flow stress peak can be observed, in contrast to low strain rates, where the materials exhibit steady-state behavior from the beginning of the hot compression process. The observations of stress-strain curves indicated high sensitivity of both materials to increasing strain rate. For Ti-10V-2Fe-3Al alloy deformed at the temperature of $900^{\circ} \mathrm{C}$, deformation took place in the single $\beta$ phase region, while for Ti$6 \mathrm{Al}-4 \mathrm{~V}$ in $\alpha+\beta$ phase region. Nevertheless, during hot compression of $\beta$ titanium alloy, higher stress value was noted at lower strain rates in comparison to the $\alpha+\beta$ titanium alloy. However, previous research (Weiss \& Semiatin, 1999) reported, that alloys with a higher concentration of alloying elements exhibit the highest flow stresses values.

Data received from plastometric tests for the investigated materials were used for the elaboration of processing maps and were the source of information on material behavior during deformation, which was applied for Finite Element Method (FEM) numerical modeling.

\subsection{Processing maps}

Processing maps were developed on the basis of the theory of DMM. Prasad et al. (1984) previously
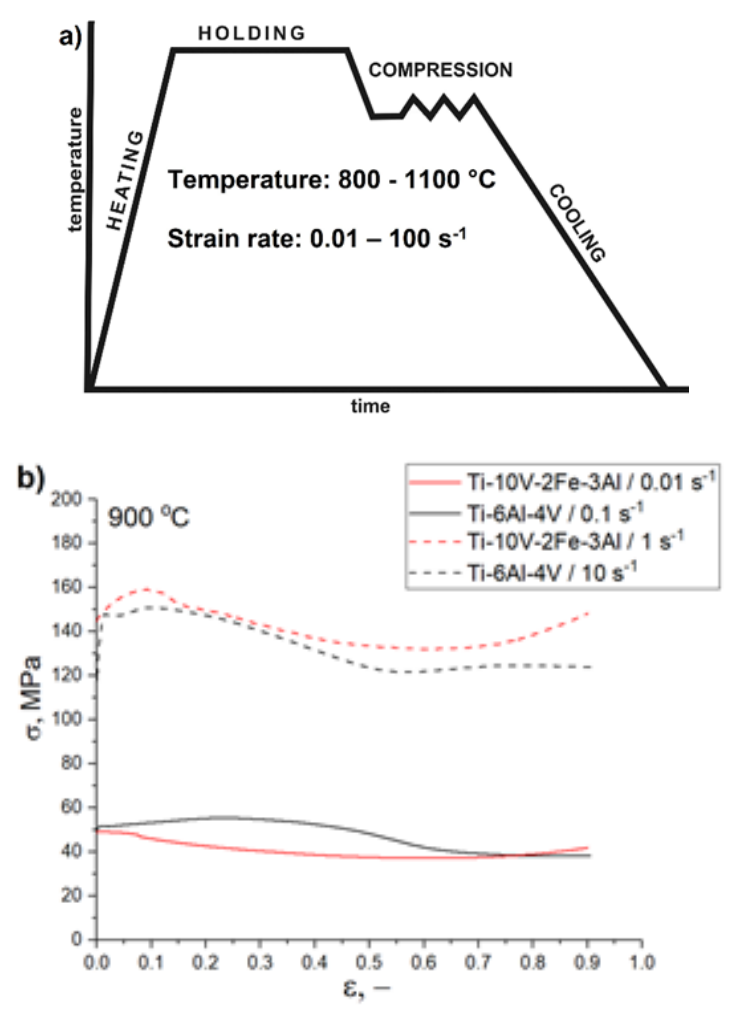

Fig. 4. Schematic representation of plastometric tests (a) and chosen true stress-true strain curves (b) for Ti-6Al-4V and Ti$10 \mathrm{~V}-2 \mathrm{Fe}-3 \mathrm{Al}$ alloys obtained at various strain rates and at the temperature of $900^{\circ} \mathrm{C}$.

used this method to describe the workability of Ti6Al-2Sn-4Zr-2Mo alloy. The total power $P$ absorbed by material during deformation can be split into two components:

$P=\sigma \dot{\varepsilon}=G+J$

In equation (1) $G$ is dissipation component representing part of energy transformed into the temperature increase and $J$ is a component representing dissipation of energy due to microstructural changes occurred during plastic deformation, such as dynamic recrystallization and recovery (DRX and dynamic recovery - DRV), phase transformation or grain refinement. These two components are calculated from the following equations:

$$
\begin{aligned}
& G=\int_{0}^{\dot{\varepsilon}} \sigma d \dot{\varepsilon} \\
& J=\int_{0}^{\sigma} \dot{\varepsilon} d \sigma
\end{aligned}
$$

Processing map contains isoclines, which represent the efficiency of power dissipation $\eta$, and instabilities regions, represented by instability criterion $\xi$. 
These two parameters are calculated from the following equations:

$\eta=\frac{J}{J_{\max }}=\frac{2 m}{m+1}$

$$
\xi=\frac{\partial \ln \left(\frac{m}{m+1}\right)}{\partial \ln (\dot{\varepsilon})}+m<0
$$

where: $m$ - the strain rate sensitivity parameter, which is defined at the constant value of the temperature and strain.

Chosen processing maps for Ti-6Al-4V (figure $5 \mathrm{a})$ and $\mathrm{Ti}-10 \mathrm{~V}-2 \mathrm{Fe}-3 \mathrm{Al}$ (figure $5 \mathrm{~b}$ ) alloy were presented in figure 5. Shaded areas represent parameters for which the $\xi$ parameter takes negative values. Deformations at those regions are considered unsafe, because of the possibility of the occurrence of the microstructural defects, such as flow localization, adiabatic shear, and as a result debonding or cracks (Liu et al., 2010). Recommended parameters are the ones where the $\eta$ parameter values are the highest. Then, the possibility of the occurrence of DRX, DRV or superplasticity is the most likely (Chuan \& Liang, 2018).

It can be observed, that regardless of the chemical composition, for titanium alloys manufactured by powder metallurgy method, instability domains occur at high strain rates. The temperature of the deformation of titanium alloys under a strain rate higher than $10 \mathrm{~s}^{-1}$ should be strictly controlled. According to the developed maps, too much undercooling of the material may result in the occurrence of defects. On the other hand, due to relatively low thermal conductivity of titanium, its alloys have a tendency to overheating during hot deformation, which also may results in a formation for example ASB. For the investigated alloys, most favorable conditions are low strain rates and the temperature between $880-990^{\circ} \mathrm{C}$ for $\alpha+\beta$ alloys and $850-940^{\circ} \mathrm{C}$ for $\beta$ alloys. The difference in temperature results from the different $\beta$ - transus temperature, which for Ti-6Al-4V alloy is about $980^{\circ} \mathrm{C}$ (Wojtaszek, 2018) and for Ti-10V-2Fe-3Al alloy is about $855^{\circ} \mathrm{C}$ (Zyguła et al., 2019).
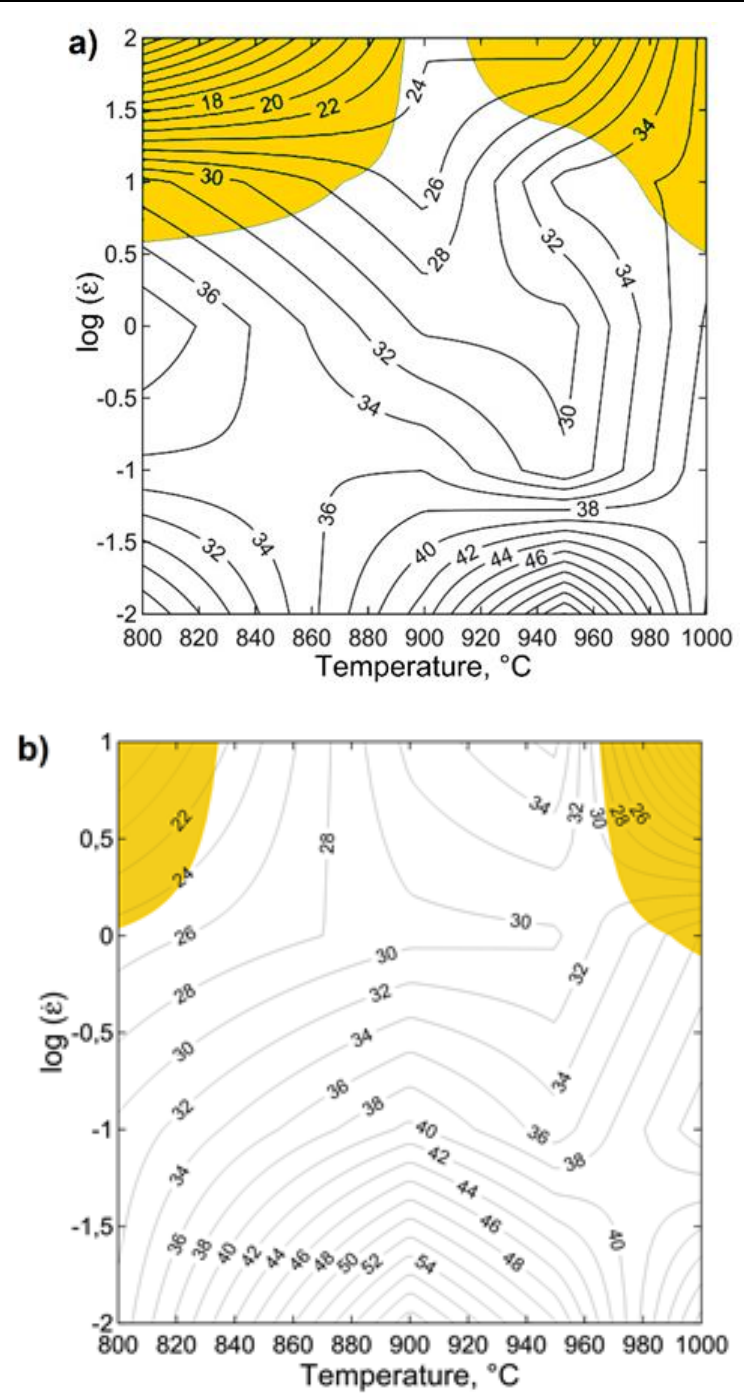

Fig. 5. Processing maps elaborated for Ti-6Al-4V (a) and Ti$10 \mathrm{~V}-2 \mathrm{Fe}-3 \mathrm{Al}(\mathrm{b})$ alloy compacts developed for a true strain of 0.9 (shaded areas with a negative $\xi$ parameter value).

\subsection{FEM simulations and process verification in industrial conditions}

The rheological characteristics of the investigated materials were developed on the basis of hot compression tests. Hot forging processes carried out on forging machines having different work dynamics were selected for FEM numerical analysis, which enabled the diversification of thermo-mechanical conditions for their application. As a result, they could correspond to different processing windows determined basing on DMM analysis. For the numerical analysis of forging selected structural part out of the investigated alloys, commercial QForm 3D software was used. The results of the numerical modeling of the hot forging of PM titanium alloys as well as its verification in industrial conditions were previously reported by Wojtaszek and Śleboda (2013, 2014), Wojtaszek et al. (2014, 2016), Wojtaszek (2018). In order to properly design and 
carry out a thermo-mechanical numerical analysis of hot forming processes of the investigated alloys obtained by powder metallurgy, it was also necessary to know its basic thermal properties and the estimated value of the friction coefficient at the metal-tool contact surface under hot working conditions. The results of such tests were implemented into numerical modeling procedures as a part of boundary conditions. The chosen results of FEM modeling were presented in figure 6a-c. According to the DMM analysis as an initial temperature of hot forging $900^{\circ} \mathrm{C}$ was selected. Deformation in such conditions should ensure avoiding the possibility of the

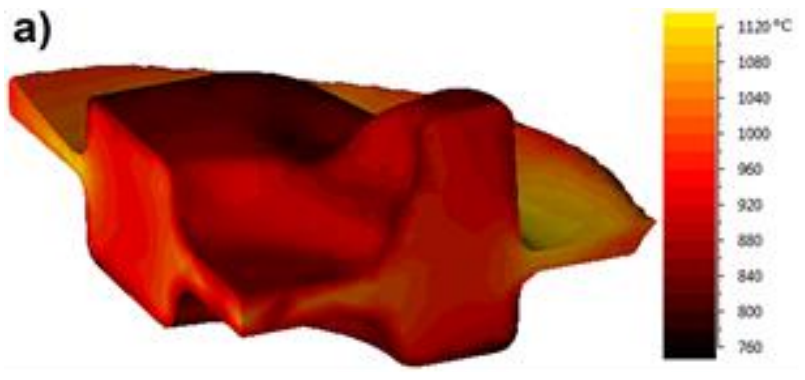

b)

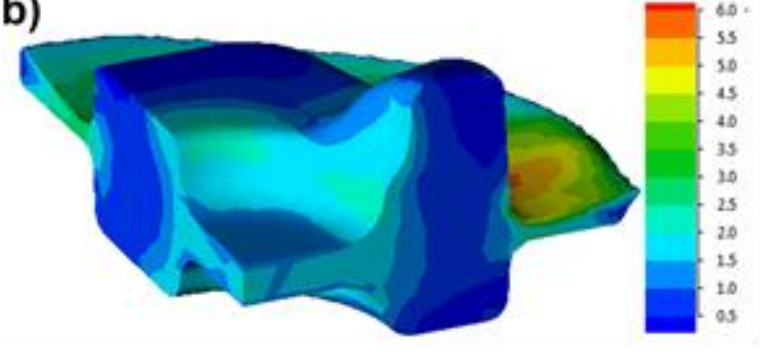

c)
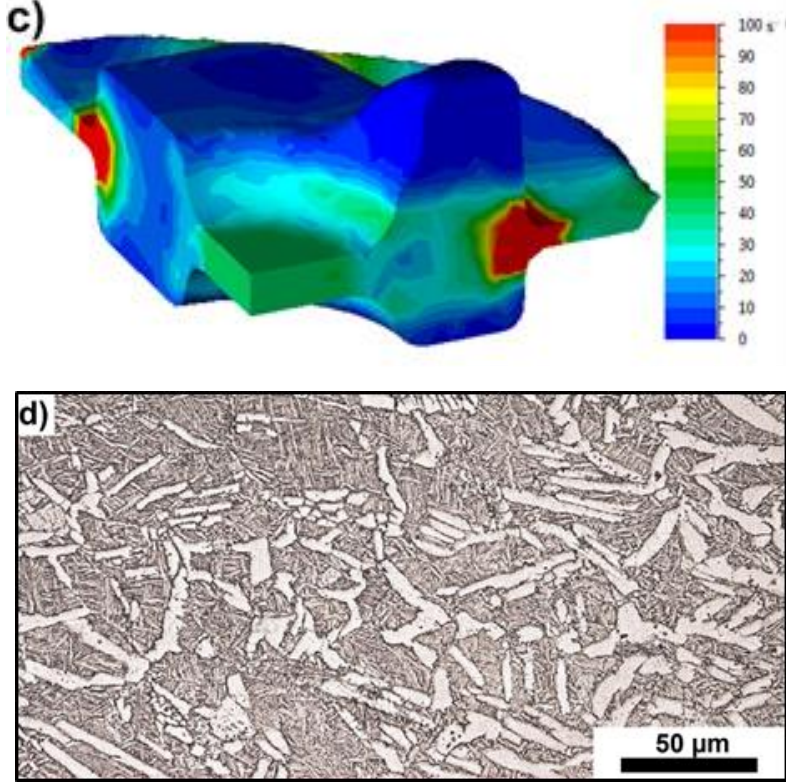

Fig. 6. Distributions of the temperature (a), plastic strain (b) and strain rate (c) obtained from FEM numerical simulations of forging of the PM Ti-6Al-4V alloy at the temperature of $900^{\circ} \mathrm{C}$; microstructure of structural part forged in industrial conditions (d). occurrence of microstructural defects during forging at high strain rates. The selected friction coefficient was 0.1 and the tools temperature was set as $300^{\circ} \mathrm{C}$. Based on the simulation results, it can be concluded that the deformation was accompanied by a sharp rise in temperature in the flash zone and in areas near it as well as in most deformed regions (e.g. "bottom" part). Analysing figure 6b, it can be observed that in the usable part of the forgings ("bottom" and flash are waste material), deformation values do not exceed 1.0, which confirms the possibility of analyzing the parameters of forging of such structural part based on the obtained process maps. Similarly, highest strain rate values are visible in regions close to flash and in "bottom". Nevertheless, only in mentioned locations in the volume of the forged part there is a possibility that strain rate will exceed $100 \mathrm{~s}^{-1}$. In the remaining volume of the structural part strain rate is in the range of $0-50 \mathrm{~s}^{-1}$. A correct filling of the die, as well as no structural defects was demonstrated. Simulation results showed that proposed deformation parameters can be successfully applied in trails in industrial conditions.

Forging trials at the industrial conditions were realized on various production lines mentioned in chapter 2. Deformation parameters matched those implemented in FEM simulation. A cylinder-shaped charge with dimensions selected as a result of FEM modelling was used. Forging was carried out on a crank press with a maximum speed of the upper tool $1 \mathrm{~m} \cdot \mathrm{s}^{-1}$ and the temperature of deformation was $900^{\circ} \mathrm{C}$. The microstructure of chosen forging obtained from PM Ti-6Al-4V alloy compact was shown in figure $6 \mathrm{~d}$. The geometry of forging obtained in industrial conditions corresponded to that of the conducted numerical simulation. In result of hot forging process relative density increased up to $99.5 \%$. The microstructure consists of $\alpha$ phase thick plates, that surround thin acicular $\alpha$ grain precipitations located on the $\beta$ phase matrix. During deformation, $\alpha$ plates that previously grew on primary $\beta$ grain boundaries were fragmented or elongated towards material flow direction. Whether the $\alpha$ plates were fragmented or elongated, depended on their initial orientation in relation to the flow direction. It was previously reported, that breakup of microstructure during hot deformation plays important role in designing the required mechanical properties (Shell \& Semiatin 1999; Li et al., 2019) 


\section{CONCLUSIONS}

Based on the performed research and obtained results, both presented in this work and in previous publications it can be stated, that proposed route of manufacturing titanium alloy structural parts, which assumes hot or cold compaction of mixture of elemental powders followed by sintering and plastic deformation, allows producing structural elements with high relative density and mechanical properties comparable to that of solid material.

Due to plastometric tests, it was possible to describe the rheology of the investigated materials and obtain useful data for the elaboration of processing maps and FEM simulations of chosen forging processes. Results of DMM analysis and numerical simulations allowed designing the most favorable processing parameters, which were applied during forging tests in industrial conditions. The correctness of these parameters was confirmed based on forging tests carried out in industrial conditions. Obtained structural parts were characterized by fine and uniform microstructure and profitable mechanical properties. Research concerning material behavior during hot processing of cold compacted and sintered Ti$5 \mathrm{Al}-5 \mathrm{Mo}-5 \mathrm{~V}-3 \mathrm{Cr}$ alloy is still being performed. Nevertheless, the results obtained so far indicated, that during the hot compression tests, in spite of favorable microstructure, also an increase in relative density of the investigated alloys can be achieved up to $95 \%$.

The results of the presented investigations indicated that proposed manufacturing technology can be competitive to conventionally used coasting route and an attractive, cost-effective alternative for the production of structural parts applied in the aviation and automotive industries.

\section{ACKNOWLEDGMENTS}

Financial support of the AGH University of Science and Technology dean grant for young researchers no. 16.16 .110 .663 is gratefully acknowledged.

\section{REFERENCES}

Ahmed, M., Savvakin, D.G., Ivasishin, O.M., Pereloma, E.V., 2017, The effect of thermo-mechanical processing and ageing time on microstructure and mechanical properties of powder metallurgy near $\beta$ titanium alloys, J. Alloys Compd., 714, 610-618.

Carman, A., Zhang, L.C., Ivasishin, O.M., Savvakin, D.G., Matviychuk, M.V., Pereloma, E.V., 2011, Role of alloying elements in microstructure evolution and alloying elements behaviour during sintering of a near- $\beta$ titanium alloy, $M a$ ter. Sci. Eng., A, 528 (3), 1686-1693.

Chouirfa, H., Bouloussa, H., Migonney, V., Falentin-Daudré, C., 2019, Review of titanium surface modification techniques and coatings for antibacterial applications, Acta Biomater. $83,37-54$.

Chuan, W., Liang, H., 2018, Hot deformation and dynamic recrystallization of a near-beta titanium alloy in the $\beta$ single phase region, Vacuum, 156, 384-401.

Dunstan, M.K., Paramore, J.D., Fang, Z.Z., Sun, P., 2019, Manipulation of microstructure and mechanical properties during dehydrogenation of hydrogen-sintered Ti-6Al-4V, Mater. Sci. Eng. A., 764, 138244.

Eisenbarth, E., Velten, D., Müller, M., Thull, R., Breme, J., 2004 , Biocompatibility of $\beta$-stabilizing elements of titanium alloys, Biomaterials, 25, 5705-5713.

Ivasishin, O. M., Savvakin, D.G., 2010, The Impact of Diffusion on Synthesis of High-Strength Titanium Alloys from Elemental Powder Blends, Key Eng. Mater., 436, 113-121.

Kim, Y., Kim, E.P., Song, Y.-B., Lee, S.H., Kwon, Y.-S., 2014, Microstructure and mechanical properties of hot isostatically pressed Ti-6Al-4V alloy, J. Alloys Compd. 603, 207212.

Li, Y., Ou, X., Ni, S., Song, M., 2019, Deformation behaviors of a hot rolled near- $\beta$ Ti-5Al-5Mo-5V-1Cr-1Fe alloy, Mater. Sci. Eng. A., 742, 390-399.

Liu, B., Li, Y.P., Matsumoto, H., Liu, Y.B., Liu, Y., Tang, H.P., Chiba, A., 2010, Thermomechanical response of particulate-reinforced powder metallurgy titanium matrix composites-A study using processing map, Mater. Sci. Eng. A., 527, 4733-4741.

Ma, X., Li, F., Cao, J., Li, J., Sun, Z., Zhu, G., Zhou, S., 2018, Strain rate effects on tensile deformation behaviors of Ti$10 \mathrm{~V}-2 \mathrm{Fe}-3 \mathrm{Al}$ alloy undergoing stress-induced martensitic transformation, Mater. Sci. Eng. A., 710, 1-9.

Prasad, Y.V.R.K., Gegel, H.L., Doraivelu, S.M., Malas, J.C., Morgan, J.T., Lark, K.A., Barker, D.R., 1984, Modeling of dynamic material behavior in hot deformation: Forging of Ti-6242, Metall. Trans. A., 15, 1883-1892.

Shell, E.B., Semiatin, S.L., 1999, Effect of initial microstructure on plastic flow and dynamic globularization during hot working of Ti-6AI-4V, Metall. Mater. Trans. A, 30, 32193229.

Singh, P., Pungotra, H., Kalsi, N.S., 2017, On the characteristics of titanium alloys for the aircraft applications, Mater. Today Proc., 4, 8971--8982.

Weiss, I., Semiatin, S.L., 1999, Thermomechanical processing of alpha titanium alloys - An overview, Mater. Sci. Eng. A., 263, 243-256.

Wojtaszek, M., 2018, Opracowanie $i$ weryfikacja cieplnomechanicznych parametrów przeróbki plastycznej wyprasek $z$ dwufazowego stopu tytanu, Wydawnictwa AGH, Kraków, (in Polish)

Wojtaszek M., Śleboda T., 2013, Thermomechanical Processing of P/M Ti-6Al-4A alloy, Proc. 22nd Int. Conf. Metall. Mater., Brno, 364-369.

Wojtaszek, M., Śleboda, T., 2014, Design and verification of thermomechanical parameters of P/M Ti6Al4V alloy forging, J. Alloys Compd., 615, 546-550.

Wojtaszek, M., Śleboda, T., Korpała, G., 2016, Hot processing of cast and PM Ti-6Al-4V alloy, Arch. Metall. Mater. 61, 1115-1120. 
Wojtaszek, M., Śleboda, T., Rumiński, M., Łuksza, J., 2014, Design and verification of the parameters of hot forging of Ti10V2Fe3Al alloy compacts, Appl. Mech. Mater., 606, 119-123.

Yang, F., Gabbitas, B., Dore, M., Ogereau, A., Raynova, S., Bolzoni, L., 2018a, On microstructural evolution and mechanical properties of Ti-5 Al-5V-5Mo-3Cr alloy synthesised from elemental powder mixtures, Mater. Chem. Phys., 211, 406-413.

Yang, F., Raynova, S., Singh, A., Zhao, Q., Romero, C., Bolzoni, L., 2018b, Producing high-quality titanium alloy by a cost-effective route combining fast heating and hot processing, JOM, 70, 632-637.

Zyguła, K., Śleboda, T., Wojtaszek, M., Korpała, G., 2017, Physical modeling of hot forging of cast and $\mathrm{P} / \mathrm{M}$ Ti-6Al4V alloy, Proc. 26th Int. Metall. Mater. Conf., Brno, 1977 1982.

Zyguła, K., Wojtaszek, M., Lypchanskyi, O., Śleboda, T., Korpała, G., Prahl, U., 2019, The investigation on flow behavior of powder metallurgy $\mathrm{Ti}-10 \mathrm{~V}-2 \mathrm{Fe}-3 \mathrm{Al}$ alloy using the prasad stability criterion, Metall. Mater. Trans. A., 50, 5314-5323.

\section{WYBRANE ASPEKTY WYTWARZANIA \\ ELEMENTÓW KONSTRUKCYJNYCH ZE STOPÓW TYTANU LĄCZĄCYCH TECHNOLOGIE METALURGII PROSZKÓW ORAZ PROCESY PRZERÓBKI PLASTYCZNEJ}

\section{Streszczenie}

Stopy tytanu są stosowane głównie w przemyśle motoryzacyjnym, lotniczym, stoczniowym i wojskowym. Ich głównymi zaletami są niski ciężar właściwy, odporność na pękanie i korozję, wysoka wytrzymałość oraz wytrzymałość zmęczeniowa. Do wad stopów tytanu można zaliczyć niską przewodność cieplną, skomplikowaną obróbkę mechaniczną i wysokie koszty produkcji. Z tego ostatniego powodu stopy tytanu są stosowane przede wszystkim do produkcji wysoce odpowiedzialnych elementów konstrukcyjnych, takich jak implanty i struktury lotnicze, podczas gdy pozostałe produkty są wytwarzane w ograniczonym stopniu. Stosując odpowiednie parametry termomechaniczne, stopy tytanu mogą być z powodzeniem kształtowane na drodze przeróbki plastycznej na gorąco. Obecnie w procesach wytwarzania elementów konstrukcyjnych stopów tytanu powszechnie stosuje się półprodukty uzyskane metodą odlewania. Jednak w tej dziedzinie prowadzone są coraz więcej badań nad wykorzystaniem materiałów opartych na metalurgii proszków. Takie podejście otwiera możliwość obniżenia kosztów produkcji. Jako materiał wyjściowy można zastosować proszki stopowe lub mieszaniny proszków elementarnych. Wykorzystanie proszków stopowych zwykle zapewnia wysokie i stabilne własności, jednak koszt produkcji takiego proszku jest wysoki. Otrzymywanie produktów ze stopów tytanu na bazie mieszaniny proszków elementarnych jest stosunkowo proste i znacznie tańsze. Dysproporcja cen powoduje, że ogromna liczba projektów badawczych zrealizowanych w ostatnich latach w zakresie wdrażania metalurgii proszków do wytwarzania produktów na bazie tytanu jest ukierunkowana na stosowanie mieszaniny proszków elementarnych, ponieważ takie podejście daje realne szanse na pomyślne wdrożenie opisanej technologii przetwarzania stopów tytanu. 